\title{
Rapid Alcoholysis of Jatropha Curcas Oil for Biodiesel Production Using Ultrasound Irradiation
}

\author{
Muh. Irwan ${ }^{1,3, *}$, Hamdani Saidi ${ }^{1}$, M.A. Rachman ${ }^{2}$, R. Ramli ${ }^{3}$, M. Marlinda ${ }^{3}$ \\ ${ }^{1}$ Institute of Hydrogen Economy (IHE), Universiti Teknologi Malaysia, \\ Jalan Sultan Yahya Petra, Kuala Lumpur 54100, Malaysia \\ ${ }^{2}$ Agency for Assessment and Application of Technology, BPPT, Kawasan Puspiptek Serpong, \\ Tangerang 15314, Indonesia \\ ${ }^{3}$ Department of Chemical Engineering, Politeknik Negeri Samarinda, \\ Jln. Dr. Ciptomangunkusumo, Kampus Gunung Lipan, Samarinda 75131, Indonesia
}

Received: 11 $1^{\text {st }}$ November 2016; Revised: $8^{\text {th }}$ March 2017; Accepted: $9^{\text {th }}$ March 2017; Available online: 27th October 2017; Published regularly: December 2017

\begin{abstract}
The biodiesel synthesis through alcoholysis process of triglyceride from Jatropha curcas using different type of alcohol, such as: methanol, ethanol, isopropyl alcohol and tert-butanol, was conducted in the presence of potassium hydroxide $(\mathrm{KOH})$ as a catalyst under $35 \mathrm{kHz}$ frequency ultrasound irradiation. The optimum conditions, such as: alcohol to jatropha oil molar ratio, concentration of catalyst, reaction temperature, and reaction time, were found to be $7: 1$ of alcohol to jatropha oil molar ratio, $0.5 \%$ of $\mathrm{KOH}$, temperature of reaction at $35{ }^{\circ} \mathrm{C}$, within the reaction times of 15 minutes. The results obtained for the different types of alcohol were $62.77 \%$, $57.93 \%, 51.64 \%$, and $46.77 \%$ for methanol, ethanol, isopropyl alcohol, and tert-butanol, respectively. Copyright (C) 2017 BCREC Group. All rights reserved
\end{abstract}

Keywords: Alcoholysis; Jatropha oil; Biodiesel; Ultrasound; fatty acid methyl ester; FAME

How to Cite: Irwan, M., Saidi, H., Rachman, M.A., Ramli, R., Marlinda, M. (2017). Rapid Alcoholysis of Jatropha Curcas Oil for Biodiesel Production Using Ultrasound Irradiation. Bulletin of Chemical Reaction Engineering \& Catalysis, 12 (3): 306-311 (doi:10.9767/bcrec.12.3.801.306-311)

Permalink/DOI: https://doi.org/10.9767/bcrec.12.3.801.306-311

\section{Introduction}

Due to the increasing demand of energy from fossil fuel sources, environmental concerns, market policies and several socioeconomic aspects including growing of population at majority of the world are driving search of viable alternative energy has gained recent significant attention [1-4]. Traditional energy sources such as fossil oil, natural gas and coal have limited reserves that are expected not to lost for an ex-

* Corresponding Author.

E-mail: irwan_tl05@yahoo.co.id (Irwan, M.)

Telp.: +62-81230077925 ; Fax.: +62-541260355 tended period. The main demand of world is projected to increase by $1.5 \%$ per year between 2007 until 2030. In fact, it can be estimated that the world may run short of fossil fuels by the year 2044 [5-6]. Biofuels, including biodiesel, wind and solar energy, coal and gas, hydro power and geothermal, are among the possible alternatives for get the new sources of energy. Two well known biofuels commercially produced are biodiesel and bioethanol [7-8].

Biodiesel is defined as a fuel comprised of mono-alkyl esters of long chain fatty acids derived from vegetable oils or animal fats [9]. The most commonly used method for synthesis biodiesel is transesterification also called alcoholy- 
sis [9-10]. Alcoholysis involves the reaction between an some alcohol and vegetable oil or animal fat that are mixtures of triglyceride. Methanol and ethanol are the most commonly used because low cost than other type of alcohol. For complete reaction need a minimum 3:1 molar ratio of alcohol to oil. Due to the fact that the alcoholysis is an equilibrium reaction, an excess of alcohol is used to displace the reaction towards biodiesel production [11-12].

Oil and alcohols are not totally miscible, so their reaction takes place at the interface and it is very slow reaction. The alcoholysis reaction can be catalyzed by acid, alkaline and enzyme. Enzyme catalyst are very expensive for industrial application $[11,16]$. The conventional method for synthesis of biodiesel is conducted in a batch reactor. Mechanical stirring is the most commonly used process for mixing some reactants and if using acid as catalyst, the time of reaction is very long (48-96 hours), even at the boiling point of the alcohol and high molar ratio of alcohol to oil needed [11,13]. If the process used alkaline catalyst, the process needs reaction time of 2-4 hours for complete reaction to biodiesel production. Several researchers was reported that the better results and industrial scale, the alkaline catalyst is the most commonly used due to low cost, easy to install and shorter reaction time [14-15]. In recent years, ultrasound a useful tool for strengthening the mass transfer of the liquid-liquid systems, has gained much more interest of many researchers [13]. For shorten the reaction time, presence of ultrasound is one method providing excellent mixing between two phases. Low frequency ultrasound is useful tool for emulsification of immiscible liquids. The collapse of the cavitation bubbles disrupts the phase boundary and causes emulsification, by ultrasonic jets that impinge one liquid on another, leading to intensive emulsification of the system $[11,17]$. In this work, the irradiation of ultrasound was used for alcoholysis process of jatropha curcas oil to shorten the reaction time and to increase percentages yield of biodiesel.

The main objectives of this work are to explain the influence of ultrasound irradiation on the alcoholysis of Jatropha curcas oil using $\mathrm{KOH}$ as a catalyst and to find the optimum conditions of the alcoholysis process.

\section{Materials and Methods}

\subsection{Materials}

Refined Jatropha curcas oil in this work was supplied from Malang, East Jawa Province, Indonesia. The various alcohols employed in this work (methanol, ethanol, isopropyl alcohol, tert-butanol) were purchased from Merck KGaA Darmstadt Germany (99.5 \%) purity. Potassium hydroxide $(\mathrm{KOH})$ as a catalyst was purchased from Merck agency with analytical grade.

\subsection{Alcoholysis procedure}

The ultrasound equipment used in this work had a working frequency of $35 \mathrm{kHz}$ (Pro'sKit digital) and operate at 160 watt. The reaction mixtures consist of jatropha oil, alcohols, such as: methanol, ethanol, isopropyl alcohol, tert-butanol, and $\mathrm{KOH}$, as alkaline catalyst. The molar ratio of alcohol to Jatropha curcas oil was $7: 1$, amount of catalyst of $0.25,0.5$, 0.75 , and $1.0 \%$ to the weight of Jatropha curcas oil, respectively. The potassium hydroxide $(\mathrm{KOH})$ was dissolved into the alcohol prior to the addition of Jatropha curcas oil and the solution was fed to the ultrasound-assisted reactor. It is assumed that the reaction was started as soon as all reactants and catalyst were fed into the ultrasound. Samples were taken at following reaction time of $5,10,15$, and $20 \mathrm{~min}$ utes. After complete of the reaction, the samples were immediately quenched in water to stop the reaction and two phases were formed. The samples were washed by the distilled water 3-4 times until the water layer becomes clear. The final stage was the heating process to remove a lot of water in the ester product. Finally, the dried biodiesel were stored.

\section{Results and Discussion}

\subsection{Composition of Jatropha curcas oil}

Varian of GC (gas chromatography) analysis was performed for identifying the fatty acids composition of Jatropha curcas oil, and the composition was showed in the Table 1.

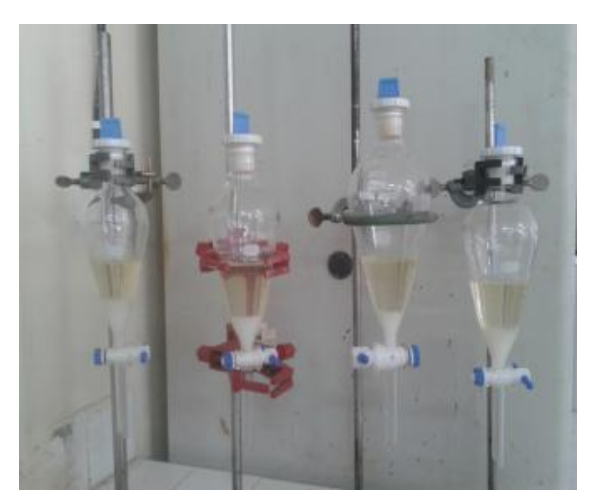

Figure 1. Experimental set up of alcoholysis of Jatropha curcas oil produce two phase materials, which are biodiesel and glycerol 
Previously, the fatty acid composition of the Jatropha curcas oil consists of palmitic acid of $15 \%$, stearic acid of $4.8 \%$, oleic acid of $27.22 \%$, linoleic acid of $32.48 \%$, linelenic acid of $3.41 \%$, and another acids [18]. Meanwhile, according Prabaningrum et al. [19] shows that the acid content in jatropha oil is palmitic acid of 17.58 $\%$, stearic acid of $9.4 \%$, oleic acid of $37.75 \%$, linoleic acid of $33.48 \%$, and other acids [19]. Different composition of free fatty acid of jatropha oil may caused by the content and effects of the fertility of soil. According to Baroi et al. [18] shows that the fatty acid composition of Jatropha curcas oil from New Delhi India, while Prabaningrum et al. [19] shows the jatropha oil from Yogyakarta or Medan, Indonesia.

\subsection{Effect of alcohol to oil molar ratio}

In the synthesis process of biodiesel through alcoholysis, the alcohol to oil molar ratio is observed to play significant role. According to the stoichiometric equation of alcoholysis, 3 moles of alcohol reacts with 1 mole of triglyceride to give 3 moles of fatty acid ester (biodiesel) and 1 mole of glycerol. In other words, molar ratio of alcohol to oil is at least 3:1. Many researchers have reported a minimum alcohol to oil molar ratio of $6: 1$ to be the optimal ratio, while Leung

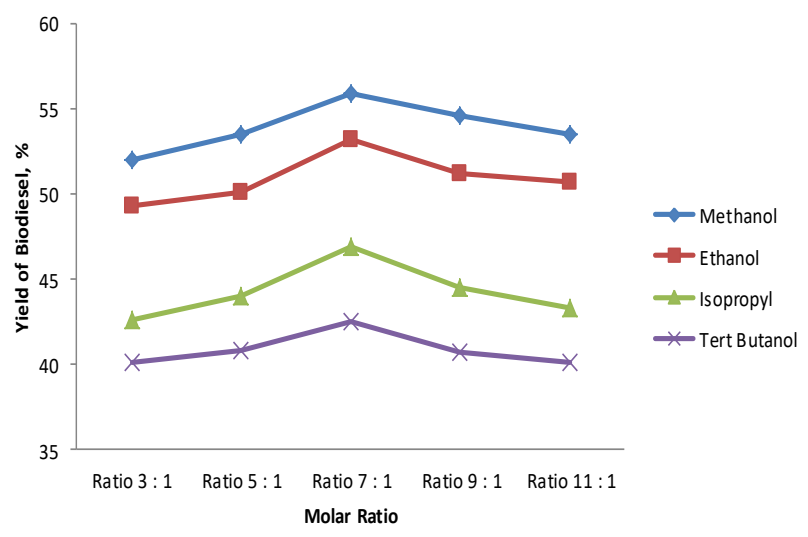

Figure 2. Effect of different type alcohol to oil molar ratio on biodiesel yield with $\mathrm{KOH}$ as a catalyst at reaction temperature $35{ }^{\circ} \mathrm{C}$ and Guo [20] reported that the minimum ratio of $7: 1$ was applied to get the maximum biodiesel production [20]. In this work, different types of alcohols to jatropha oil molar ratios of $3: 1,5: 1,7: 1,9: 1$, and $11: 1$ were used to investigate the effect of variation of alcohol/jatropha oil molar ratio on the biodiesel yields as presented in Figure 2. At lower alcohol/jatropha oil molar ratio, the biodiesel yields were found to be relatively lower for all types of alcohol. The biodiesel yields increased with increasing alcohol to jatropha oil molar ratio and reached the highest yields at molar ratio of 7:1. Other studies also suggested the optimum molar ratio of 5:1 to 8:1 for maximum biodiesel yield [21].

\subsection{Effect of catalyst concentration}

The catalyst concentration in the alcoholysis is an important factor that could affect in the biodiesel yield. Before the alcoholysis was carried out, potassium hydroxide $(\mathrm{KOH})$ as a catalyst was dissolved in alcohol first to produce a potassium methoxide. A range of potassium hydroxide $(\mathrm{KOH})$ as catalyst amount of $0.25,0.50,0.75$, and $1.00 \% \mathrm{wt}$ were used to investigate the effect of catalyst concentration on the biodiesel yield. The biodiesel yields against different catalyst amount are presented in Figure 3. The experimental result shows that the yield of biodiesel increases with increased catalyst amount. However, the rate of the increasing yield was dropped when catalyst concentration was increased beyond $0.50 \%$. It was observed that the maximum yield of biodiesel of $0.50 \%$ at potassium hydroxide $(\mathrm{KOH})$ was higher than other $\mathrm{KOH}$ concentration. The maximum yield of biodiesel of $62.77 \%$ was obtained when using $0.50 \% \mathrm{w} / \mathrm{w} \mathrm{KOH}$ concentration in 15 minutes irradiation time.

The biodiesel yield significantly increased due to increasing of catalyst concentration, and produced the highest yields at the $\mathrm{KOH}$ amount of $0.50 \%$. The highest biodiesel yields of $50.81 \%$ were found which is highest compared to other types of alcohol. The increased yield of biodiesel with the increase amount of $\mathrm{KOH}$ as catalyst was believed to be due to the

Table 1. Fatty acid composition of Jatropha curcas oil

\begin{tabular}{lccc}
\hline Fatty Acid & Molecular Formula & Structure & Composition (\%) \\
\hline Palmitic acid & $\mathrm{C}_{16} \mathrm{H}_{32} \mathrm{O}_{2}$ & $\mathrm{C} 16: 0$ & 14.20 \\
Stearic acid & $\mathrm{C}_{18} \mathrm{H}_{36} \mathrm{O}_{2}$ & $\mathrm{C} 18: 0$ & 6.90 \\
Oleic acid & $\mathrm{C}_{18} \mathrm{H}_{34} \mathrm{O}_{2}$ & $\mathrm{C} 18: 1$ & 43.20 \\
Linoleic acid & $\mathrm{C}_{18} \mathrm{H}_{32} \mathrm{O}_{2}$ & $\mathrm{C} 18: 2$ & 34.30 \\
Others acids & - & - & 1.40 \\
\hline
\end{tabular}


increased solubility of methanol into feedstock oils that enhanced biodiesel conversion reaction [22].

\subsection{Effect of reaction time}

The reaction time also plays significant role in the optimization of biodiesel yield that allows completion of the biodiesel alcoholysis process. In order to optimize the ultrasound irradiation time, the various ultrasound irradiation times were selected to be $5,10,15$, and 20 minutes at constant of other parameters (alcohols to jatropha oil molar ratio of $7: 1$, potassium hydroxide $(\mathrm{KOH})$ as catalyst amount of $0.50 \%$ weight, reaction temperature of $35{ }^{\circ} \mathrm{C}$ ). Figure 4 shows the influence of ultrasound irradiation time at the alcohol to jatropha oil molar ratio of $7: 1$ and at the optimum catalyst concentration. The yield of biodiesel were found to be increased significantly with the increasing reaction time and reaching maximum values at the reaction time of 15 minutes and the highest yields of $62.77 \%$ for methanol type of alcohol which was higher than other types of alcohol which may be due to the methanol is having the shortest carbon chain.

Other study was also reported that the reaction time affected the yield by alcoholysis process from vegetable oil feedstock [23]. A research conducted by Rustamaji et al. [24] obtained conversion of $79.65 \%$ at ratio of methanol to jatropha oil of 9:1 [24]. In this work, although the yield is lower than other research, the ratio of jatropha oil methanol is $7: 1$ and is carried out at room temperature.

\subsection{Effect of the presence of ultrasound}

The effects of ultrasound assist on alcoholysis process is a purely physical nature. Jatro-

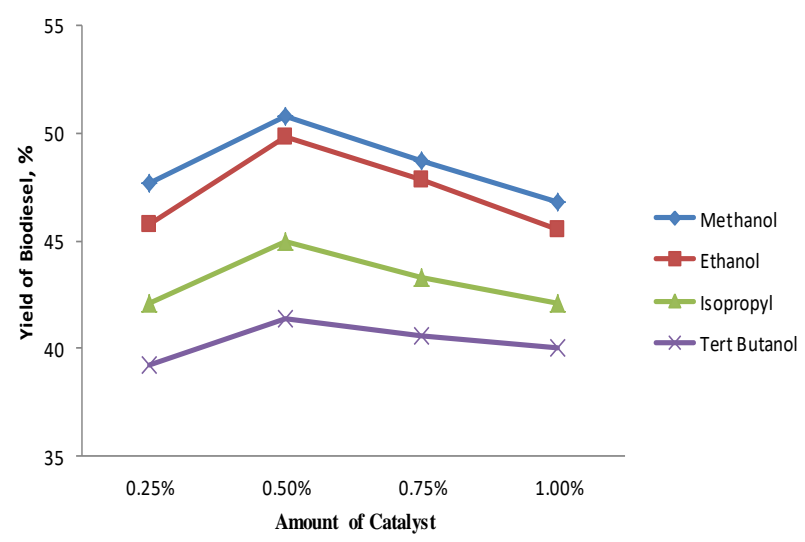

Figure 3. The effect of catalyst amount on biodiesel yield at different types of alcohol, at alcohol/oil molar ratio of $7: 1$ and reaction temperature of $35^{\circ} \mathrm{C}$ pha oil and alcohols are not totally miscible, so their reaction takes place at the interface and it is very slow reaction. In the conventional batch reactor, a mechanical stirring is the most commonly used process for mixing some reactants, and if using acid as a catalyst, the length time of reaction is very long (48-96 hours). The ultrasound irradiation can accelerate mass transfer rate between the immiscible liquid of reactants as well as the formation of emulsification. When the acceleration effect enhance the reaction activity between triglyceride and alcohol in the presence of catalyst, the rate of biodiesel exchange reaction under ultrasound irradiation would become faster than the mechanical stirring or conventional method [12].

\section{Conclusions}

It can be concluded that the product of biodiesel was depended upon the kind of alcohols in which the number of carbon in alcohols increases, the reaction rate was decreased. The optimum condition for the biodiesel production under the ultrasound assisted was the molar ratio of alcohol to jatropha oil of $7: 1$, catalyst concentration of $0.5 \%$, and reaction time of 15 minutes at room temperature. The type of alcohol which can produce the best biodiesel yield were methanol.

\section{Acknowledgement}

The first author thanks to the management and staff of Chemical Engineering Department, Politeknik Negeri Samarinda, for their support for use of laboratory and chemical materials to success this work.

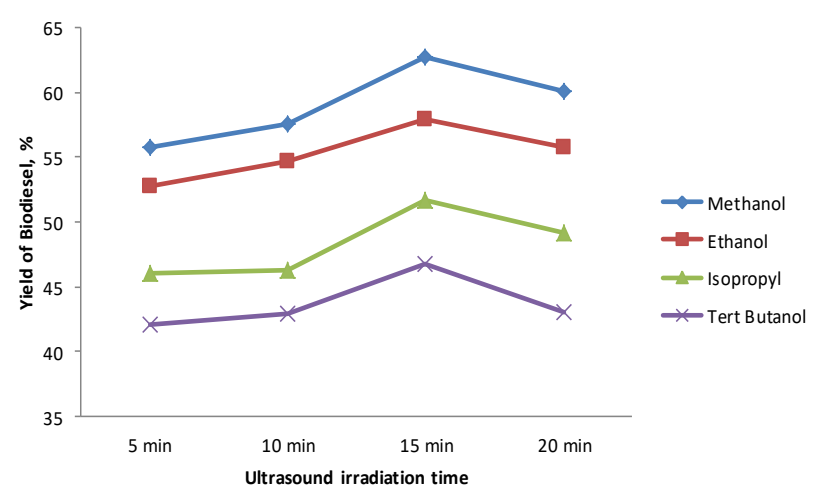

Figure 4. Effect of reaction time on biodiesel yield with different type of alcohol, keep other parameters (alcohol/oil molar ratio of $7: 1$, catalyst amount of $0.50 \%$, at reaction temperature $\left.35{ }^{\circ} \mathrm{C}\right)$ 


\section{References}

[1] Verma, P., Singh, V.M. (2014). Assessment of Diesel Engine performance using Cotton Seed Biodiesel. Integrated Research Advances, 1(1): 1-4.

[2] Istadi, I., Pramudono, B., Suherman, S., Priyanto, S. (2010). Potential of $\mathrm{LiNO}_{3} / \mathrm{Al}_{2} \mathrm{O}_{3}$ Catalyst for Heterogeneous Transesterification of Palm Oil to Biodiesel. Bulletin of Chemical Reaction Engineering \& Catalysis, 5(1): 51-56.

[3] Dorado, M.P., Ballesteros, E., Mittelbach, M., Lopes, F.J. (2004). Kinetic Parameters Affecting the Alkali-Catalyzed Transesterification Process of Used Olive Oil. Energy \& Fuels, 18: 1457-1462.

[4] Manh, D.V., Chen, Y.H., Chang, C.C., Chang, M.C., Chang, C.Y. (2011). Biodiesel Production from Tung Oil and Blended Oil via Ultrasonic Transesterification Process. Journal of the Taiwan Institute of Chemical Engineers, 42: 640-644.

[5] Pathak, V., Paul, A. (2013). Experimental Investigation of Performance \& Emission Characteristics of Diesel Engine Working on Diesel and NOME with Ethanol and Triacetin Blends. International Journal on Modern Engineering Research, 3(5): 2792-2796.

[6] Ayuk, A.A., Umunakwe, E.C., Ejele, A.E. (2011). Optimum Requirements for the Synthesis of Biodiesel using Fatty Acid Distillates. Journal of Emerging Trends in Engineering and Applied Sciences, 2(6): 897-900.

[7] Rodrigues, S., Mazzone, L.C.A., Santos, F.F.P., Cruz, M.G.A., Fernandes, F.A.N. (2009). Optimization of the Production of Ethyl Esters by Ultrasound Assisted Reaction of Soybean Oil Ethanol. Brazilian Journal of Chemical Engineering, 26(2): 361-366.

[8] Supranto, S. (2013). Palm Oil Transesterification Processing to Biodiesel using a Combine of ultrasonic and Chemical Catalyst. Pertanika Journal of Science \& Technology, 21(2): 567-580.

[9] Ginting, M.S.A., Azizan, M.T., Yusup, S. (2012). Alkaline In Situ Ethanolysis of Jatropha Curcas. Fuel, 93: 82-85.

[10] Murugesan, A., Umarani, C., Chinnusamy, T.R., Khrisnan, M., Subramanian, R., Neduzchezhain (2009). Production and Analysis of Bio-diesel from Non-Edible Oils - A Review. Renewable \& Sustainable Energy Reviews, 13: 825-834.
[11] Stavarache, C., Vinatoru, M., Nishimura, R., Maeda, Y. (2005). Fatty Acids Methyl Esters from Vegetable Oil by Means of Ultrasonic Energy. Ultrasonic Sonochemistry, 12: 367372.

[12] Hanh, H.D., Dong, N.T., Okitsu, K., Nishimura, R., Maeda, Y. (2009). Biodiesel Production through Transesterification of Triolein with Various Alcohols in an Ultrasonic Field. Renewable Energy, 34: 766-768.

[13] Yin, X., Ma, H., You, Q., Wang, Z., Chang, J. (2012). Comparison of Four Different Enhancing Methods for Preparing Biodiesel through Transesterification of Sunflower Oil. Applied Energy, 91: 320-325.

[14] Azcan, N., Danisman, A. (2007). Alkali Catalyzed Transesterification Oils by Microwave Irradiation. Fuel, 86: 2639-2644.

[15] Syam, A.M., Maulinda, L., Ibrahim, I., Muhammad, S. (2013). Waste Frying Oils-Based Biodiesel: Process and Fuel Properties. Smart Grid and Renewable Energy, 4: 281-286.

[16] Keera, S.T., El Sabagh, S.M., Taman, A.R. (2011). Transesterification of Vegetable Oil to Biodiesel Fuel Using Alkaline Catalyst. Fuel, 90: $42-47$.

[17] Vyas, A.P., Verma, J.L., Subrahmanyan, N. (2011). Effects of Molar Ratio, Alkali Catalyst Concentration and Temperature on Transesterification of Jatropha Oil with Methanol under Ultrasonic Irradiation. Advanced in Chemical Engineering and Science, 1: 45-50.

[18] Baroi, C., Yanful, E.K., Bergougou, M.A. (2009). Biodiesel Production from Jatropha curcas Oil using Potassium Carbonate as an Unsupported Catalyst. International Journal of Chemical Reactor Engineering, 7: 1-18.

[19] Prabaningrum, N., Ismail, L.B., Subbarao, D. (2014). In-Situ Methanolysis of Jatropha curcas seeds in Soxhlet Extractor, Advanced Materials Research, 917: 72-79.

[20] Leung, D.Y.C., Guo, Y. (2006). Transesterification of Neat and Used Frying Oil : Optimization for Biodiesel Production, Fuel Process Technology, 87(10): 883-890.

[21] Jitputti. J., Kitiyanan, B., Rangsunvigit, P., Bunyakiat. K., Attanatho, L., Jenvanitpanjakul, P. (2006). Transesterification of Crude Palm Kernel Oil and Crude Coconut Oil by Different Solid Catalyst. Chemical Engineering Journal, 116(1): 61-66.

[22] Hoque. M.E., Singh, A., Chuan, Y.L. (2011). Biodiesel from Low Cost Feedstocks : The Effects of Process Parameters on the Biodiesel Yield. Biomass and Bioenergy, 35(4): 15821587. 
[23] Demirbas, A. (2002). Biodiesel from vegetable oils via Transesterification in Supercritical Methanol. Energy Conversion and Management, 43(17): 2349-2356.
[24] Rustamaji, H., Budiman, A., Sulistyo, H. (2010). Alkoholisis Minyak jarak Pagar Dengan Katalisator Asam Padat. Seminar Rekayasa Kimia dan Proses, 4-5 Agustus, 2010.

Selected and Revised Papers from The $2^{\text {nd }}$ International Seminar on Chemistry (ISoC 2016) (Surabaya, 26-27 July 2016) (http://chem.its.ac.id/isoc-2016/) after Peer-reviewed by Scientific Committee of ISoC 2016 and Peer-Reviewers of BCREC journal 